\title{
Solar energy as a potential contributor to help bridge the gap between electricity supply and growing demand in Iraq: A review
}

\author{
Sulala Al-Hamadani \\ School of Architecture and Built Environment, University of Newcastle, Australia \\ School of Planning and Geography, Cardiff University, UK
}

\begin{tabular}{l}
\hline \hline Article Info \\
\hline Article history: \\
Received May 27, 2020 \\
Revised Jun 7, 2020 \\
Accepted Jul 3, 2020 \\
\hline
\end{tabular}

Keywords:

Electricity

Growing demand

Renewable sources

Solar energy

Supply

\begin{abstract}
The pivotal role of electricity is as an enabler for every other sector in any economy. Adequate electricity supply is a vital input for the economic growth and in a range of key industries. Unfortunately, the electricity sector in Iraq has been an unsustainable fiscal burden on successive Iraqi governments yet it has not been able to meet the growing demand. Iraq's electricity sector and government's decision makers should look for a longterm solutions and strategies to meet the current and future demand, by taking important steps towards fostering a reliable, affordable, and sustainable electricity system in the years and decades to come. Also, Iraqi government and ministry of electricity in particular should understand that electricity is basic service and right of Iraqis, and many nations have overcome this kind of problem decades ago. Overcoming this problem will help refueling Iraqi economy and enable it to stand on its feet again. Renewable energy resources, and solar in particular could be part of the solution. This paper aims to highlight the importance of solar energy in Iraq as a potential contributor to help bridge the gap between electricity supply and growing demand. Also, it discusses the solar energy opportunities with challenges facing other renewable energy sources in Iraq.
\end{abstract}

This is an open access article under the CC BY-SA license.

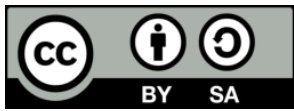

\section{Corresponding Author:}

Sulala Al-Hamadani,

School of Architecture and Built Environment,

University of Newcastle,

University Dr, Callaghan NSW 2308, Australia.

Email: Sulala.AlHamadani@uon.edu.au

\section{INTRODUCTION}

Globally, there is an increased demand for energy, especially electrical energy. This coupled with the rise of issues such as climate change, fossil fuel depletion, the increase and recent fluctuations in oil prices and their cumulative impact on the economies and renewable energy sources. All of these issues encourage the investigation of using solar, wind and other renewable energies for the generation of electrical power [1-2]. There are many different kinds of renewable energy sources like geothermal, biofuel, tidal and so on, but - as this paper will argue - solar energy is more available and accessible than other kinds in the Middle Eastern countries, and Iraq in particular.

Solar energy is a clean and renewable energy source with potential in many areas around the world. Solar power generation demand increases worldwide as many countries aim to reach goals for emission reduction and renewable power generations [3]. Solar energy exploitation can be achieved through the solar thermal and solar photovoltaic (PV) routes for various applications [4]. In 2014, the global investment in 
renewable energy has reached USD 270 billion, accounting for 59\% of net additions to global power capacity [5]. As a leading sector, solar energy was the dominant sector, accounting for 55\% of total the new investment in non-hydro renewable energy. Most of the investment in the solar energy sector is dedicated to solar photovoltaics (solar PV). This resulted in a cumulative global solar PV installed capacity of $177 \mathrm{GW}[5]$.

Technological advancements in solar PV and the fast decreasing costs mean that unsubsidized solar power is already economically feasible in some regions of the world. The increase in the worldwide expansion of solar PV was dramatically rapid. In 2000, the global total PV installations represented 1.8 GW, and increased to reach $71.1 \mathrm{GW}$ in 2011 with an annual growth rate of 44\%. The Global cumulative PV installations reached about $106 \mathrm{GW}$ [6]. The leading countries in solar PV based power are Japan, Germany, the UK, China, Spain and Italy, these countries have managed to integrate PV based power in their electricity production [7]. In 2012, European capacity for PV electricity was $17.2 \mathrm{GW}$, and it is expected to reach 48 GW by 2017 [8]. The total global solar power capacity is forecasted to grow from $98 \mathrm{GW}$ in 2012 to $308 \mathrm{GW}$ in 2018 [9].

Fortunately, Iraq lies within the high potential locations for solar power plants, these are United State of America south west, Mediterranean European countries, Middle East and Near East, Iran and India deserts, Pakistan, China and Australia [9-10]. The purpose of this paper is to highlight the importance of solar energy as a potential contributor to help meet the growing demand of electricity in Iraq, and compare its potentiality with other sources of renewable energy in Iraq.

\section{OVERVIEW OF IRAQ'S ELECTRICITY STATUS}

The electricity sector plays a critical role in the socioeconomic development of post-war countries such as Iraq [11-12]. Iraq has experienced three wars, civil unrest, and economic sanctions during the last four decades, which devastated the power system. The rise in Iraqis' income after the 2003 war has led to an increase in the consumption of electricity for household appliances. Catching up and keeping pace with rising demand for electricity is critical to Iraq's national development [13]. Power stations in Iraq produce more electricity than ever before, but power cuts are still being experienced on a daily basis in many parts of Iraq. Despite a considerable growth in grid-based electricity capacity in recent years, where the peak net daily production in 2011 was around $70 \%$ higher than 2006, it is still far from being adequate to meet demand. The net capacity accessible at peak in 2011 was about $8 \mathrm{GW}$ while the estimated requirement of the net capacity to meet peak demand was $15 \mathrm{GW}$, which means about $7 \mathrm{GW}$ was needed to close the gap between supply and demand. Iraq is in need of around $70 \%$ more netpower generation capacity to be able to meet full electricity demand [14].

This supply gap for electricity in Iraq has led to the widespread use of back-up private diesel or petrol generators. Based on a survey conducted by Iraq knowledge network in 2012, about $90 \%$ of Iraqi households supplement the public network with private diesel or petrol generators, these generators are either a private household or a shared generator with different sizes and capacities operating at neighbourhood level [15]. These private generators represent a financial burden on both the Iraqi government and its citizens. Iraqis spent nearly USD 80 billion on purchasing electricity produced from private diesel generators while the Iraqi's government subsidizes the fuel of these shared generators [16]. Private diesel generators presently play a crucial role in reducing Iraq's shortfall in electricity supply, they help reduce the number of blackouts. However, the price of the electricity supplied by these private generators to the Iraqi consumers is significantly higher than grid electricity. Residential customers are paying 10 to 15 times more for the electricity provided from private generators than from the grid. Besides being an expensive and inconvenient method to supply electricity for Iraqis, private diesel generators also contribute to local air pollution [17].

The Iraqi government's spending on improving and reconstructing the faltering power system was around USD 41.5 billion during the period 2004-2012. That includes USD 17 billion, which was financed from the country's oil revenue, spent on upgrading existing power stations and setting up new generators. Despite the efforts of subsequent Iraqi governments to improve the national electricity system, and the Iraqis to try to fill some of the electricity supply gap, the average availability of electricity to consumers (from all sources) was limited in 2011 to about 11-19 hour per day varying across the Iraqi provinces. By May of 2014, the Iraqi government was confident that its citizens would finally benefit from 24 hours of electricity supply based on its plan to add $8 \mathrm{GW}$ of generation capacity to reach $20 \mathrm{GW}$ by the end of 2015 [18]. However, because of national security issues, the ministry of electricity instead announced grid losses of more than $8 \mathrm{GW}$, where Iraqis were back to having electricity that was provided five to eight hours a day at best, and wary of fresh promises from the ministry that production will recover to 12 GW by summer 2015 [18]. 
This deep-seated gap between supply and demand is estimated to have caused some US $\$ 40$ billion in annual losses for the Iraqi economy [19], and the problem looks likely to continue. Based on recent studies, Iraq electricity demand will continue growing where total peak demand is likely to reach anywhere between 50 to $60 \mathrm{GW}$ by 2030, which exceeds the ministry of electricity forecast peak demand, which was about $35 \mathrm{GW}$ as in Figure 1 [19, 20].

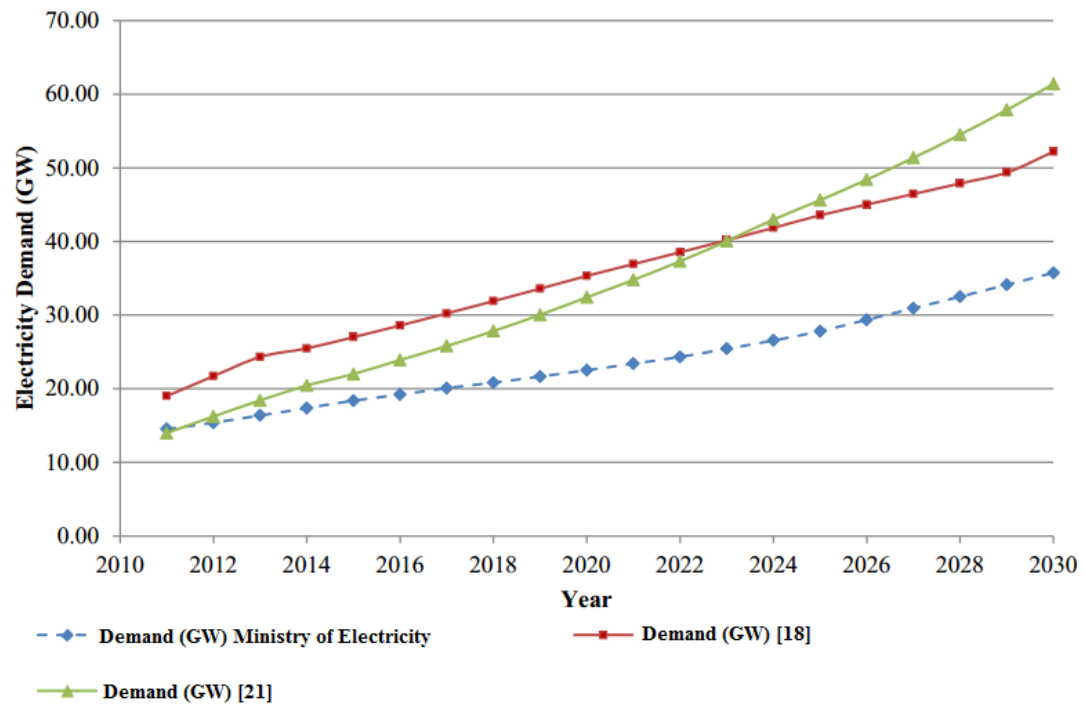

Figure 1. Electricity demand forecast in Iraq [19]

\section{MAIN CAUSES OF THE GROWTH IN ELECTRICITY DEMAND IN IRAQ}

\subsection{The rise in gross domestic product}

The considerable increase in the growth rate for GDP after 2003 was due to a sharp increase in crude oil prices. However, as the world demand for oil changes, and Iraqi economy depends largely on oil export revenues, it will be difficult to accurately forecast the exact growth in Iraq's GDP. Nevertheless, the annual growth almost exceeded 10 percent in 2012. According to the International Energy Agency (IEA) forecasted estimates, the central scenario for the GDP growth will be 10.6 percent per annum during 2010-2020 and is expected to decline gradually thereafter to settle at around 8.78 percent in the next two decades [21].

\subsection{Low electricity tariff}

As shown in Figure 2, Iraq is among the counties that have the world's lowest electricity prices [21]. The current tariff levels for the five consumer categories are largely subsidized, ranging between 0.85 and 4.50 US $\notin / \mathrm{kWh}$ (weighted average is US $\varnothing 1.85 / \mathrm{kWh}$ ), which is far from being sufficient to cover the costs and almost eight times lower than the Organization for Economic Co-operation and Development (OECD) countries' average household electricity price in 2010 of $16 \mathrm{US} \notin / \mathrm{kWh}$ [20]. Based on the Ministry of Electricity website, the cost covering tariff is about $11.30 \mathrm{US} \phi / \mathrm{kWh}$. This high cost recovery is mainly resulting from the high technical and non-technical losses in the transmission and distribution system. The specific analyses as to how much a tariff increase could reduce electricity demand in Iraq is not available. But the low electricity tariff is definitely one of the factors likely to increase the growth of demand based on other countries' experience. 


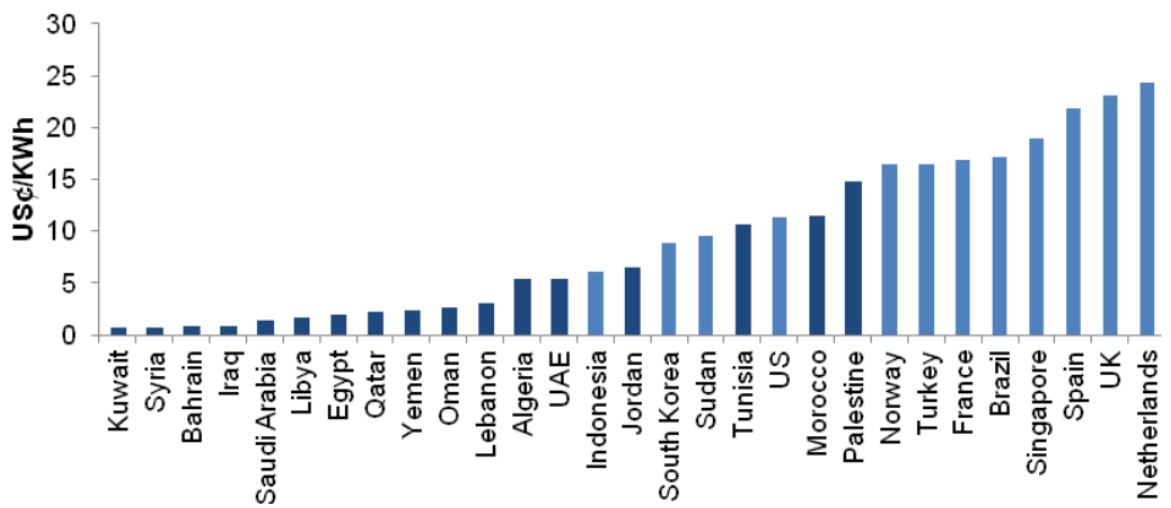

Figure 2. Cross-country comparison of average residential electricity prices in selected MENA and nonMENA countries, 2008 [21]

\subsection{Population growth and increased housing demand}

The growth in population is a major contributor in the increased demand for electricity. As of June 2011, Iraq population was 33.3 million, and it is expected to reach 55.85 million by 2030 [22]. It is clear that in the next 20 years, the population will apply huge pressure on the energy resources of the country. The electrification of urban areas especially the capital Baghdad will continue to increase, as more houses will be required over the coming years with the current continuation of inadequacy in housing of more than 1 million housing units [23]. The predicted number of housing stock will reach 8.4 million units by 2030 with the current average ratio of population to housing stock. It is anticipated that 97 percent of the households will be connected to the electricity grid by 2030 compared with 79 percent in 2012 . Hence, the number of customers is expected to double from 3.94 million connected households to 8.40 million in 2030 [23]. As a result, although one might recognize potential for energy efficiency and demand management, these demographic and economic factors are likely to drive upwards overall electricity consumption in Iraq.

\section{IRAQ'S FOSSIL-FUEL DEPENDENCE IN ELECTRICITY GENERATION}

Iraq is already the world's third-largest oil exporter [24] and has the resources and plans to increase rapidly its oil and natural gas production as it recovers from three decades punctuated by conflict and instability. Success in developing Iraq's hydrocarbon potential and effective management of the resulting revenues can fuel Iraq's social and economic development [25]. Iraq was the world's seventh largest producer of crude oil in 2013 and is currently OPEC's second biggest producer. Iraq represents a sizeable part of global oil supplies, accounting for about 4 percent of global oil production in the first quarter of 2014 [26]. In 2010, Iraq's Ministry of Oil increased its figure for the country's proven reserves to 143 billion barrels, almost $25 \%$ more than the previous 115 billion barrels. The new reserve estimate gives Iraq the fifth-largest proven oil reserves in the world and the third-largest conventional proven oil reserves after Saudi Arabia and Iran [27, 28]. According to the IEA, Iraq produced roughly 3.4 million b/d in May 2014 [29]. The IEA's medium-term outlook forecasts that Iraqi production could reach 4.8 million b/d by 2018 . Most of Iraqi oil reserves are still unexploited which may make Iraq a leading country in the world oil market in future. Iraq's potential to increase oil production in the coming decades is seen by many analysts as a key component to both Iraq and global growth. According to the IEA's 2013 World Energy Outlook forecasts, Iraqi crude and Natural gas liquids (NGLs) production to rise to 5.8 million b/d by 2020 and to 7.9 million b/d by 2035 in the base case scenario, making it the single largest contributor to global oil supply growth through 2035 [18]. If Iraq manages to increase its oil production exponentially, in the next decades, Iraq can beat Saudi Arabia in oil production and exportation.

Iraq's economy is largely dependent on the oil sector, which generates more than 95 percent of export earnings and more than 60 percent of the country's GDP [30]. Since Iraq has very rich fossil energy resources, little attention has been paid so far to explore alternative energy production and renewable resources for electricity production. As in Figure 3, electricity generation in Iraq is largely dependent on fossil fuels, which account for about 86.3 percent of the main grid electricity source, meanwhile the share of renewable energy is 13.7 represented by only hydropower [20]. 


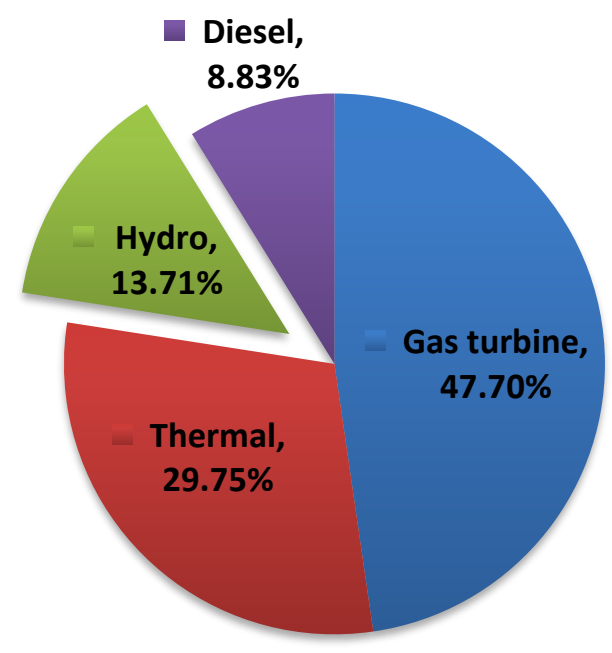

Figure 3. Iraqi electricity generation profile [20]

\section{SOLAR ENERGY IN IRAQ}

Aside from hydroelectricity, other forms of renewable energy have not been adopted on a large scale due to the fact that oil is relatively cheap and easily accessible in Iraq. There are no incentives to look for alternative forms of energy at this time. In addition, protecting the environment is not a top priority in Iraq due to the rise of many other urgent issues such as fighting terrorism and plunging oil prices. But the electric power needed in Iraq is not enough to meet the power demand of domestic and industrial sectors. In addition, the electricity sector can help Iraq's economy to stand on its feet again, which in return achieves the Iraqi's longing for long-awaited peace and prosperity. Given this, there is a strong case to search urgently for alternative energy sources, particularly potential resources for renewable energy, such as solar and wind, which are clean, inexhaustible, and environmentally friendly [31]. Among the non-hydro renewable energy sources in Iraq, solar energy as an alternative energy to conventional means of electricity generation has the strongest potential. Indeed, as many other nations in the Middle East, interest in solar energy has increased in Iraq [32]. According to the country's energy master plan, around $24.4 \mathrm{GW}$ of new capacity will be added due to 2017, with $0.4 \mathrm{GW}$ of renewable energy, mainly solar energy [33]. There are various factors indicating that solar energy is the most suitable source of renewable energy in Iraq, which are discussed in more detail as follows.

\subsection{Excellent solarity and geography of Iraq}

In Iraq, they say "safya dafya صافيه دافيه" meaning everything is fine - literally, "sunny and warm." Safya dafya could also characterize the forecast for solar power development in Iraq, as the nation's ample sunshine and flat, open land near population centres make Iraq one of the best locations in the world for solar power [34]. Iraq is known for long hours of sunshine. Studies have shown that Iraq receives more than 3000 hours of solar radiance per year in Baghdad alone [33]. The range of the hourly solar intensity varied between $416 \mathrm{~W} / \mathrm{m} 2$ in January to $833 \mathrm{~W} / \mathrm{m} 2$ in June. Even the hours of sunshine observed in Spain cannot compete with the levels in Iraq [32]. Iraq is located at the south-west of Asia. Iraq lies between latitudes 29 50 and 37220 north, and between longitudes 38450 east and 48 450. The area of Iraq is $435052 \mathrm{~km}^{2}$. The investigation of global solar radiation intensity in Iraq has been conducted by many researchers [35, 36]. Abdul-Wahid and Hassan [37] have examined different sites in Iraq, those are in the southern region consist of Al-Basrah, Al-Nasriya, AlSamawa, and Al-Amara, the middle consists of Baghdad, Haditha, Al-Rutba, Kerbala, Al-Hai, Al-Najaf and Al-Diwaniya and the northern part of Iraq includes Kirkuk, Khanaqin, Sulaymania, Al-Mosul and Zakho. As can be seen from the Figure 4 that the net radiation in southern and middle regions is higher than in the northern part of Iraq. 

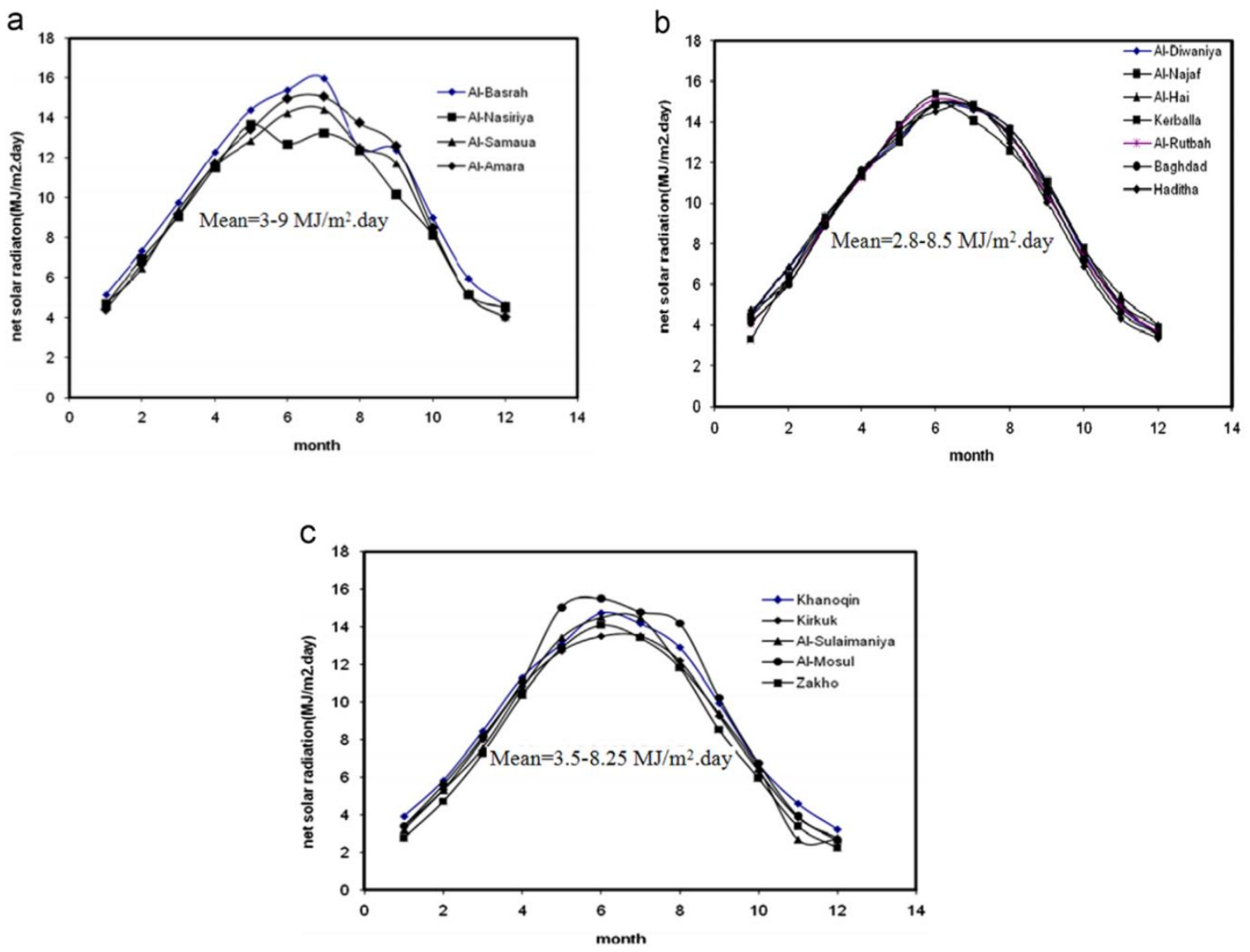

Figure 4. The net solar radiation (a) (southern region of Iraq), (b) (middle to west of Iraq) and (c) (northern region of Iraq) [37]

The monthly mean of daily solar radiation, sunshine duration, maximum temperature and relative humidity were collected from the archives of Iraqi meteorological office [38]. The daily data collected through five years from Baghdad, Mosul and Ar-Rutbah which represented middle, north and west of Iraq as in Table 1. As presented in Table 1, it is clearly noted that the highest radiation is at June, July and August, while January and December are lowest one. Meanwhile, Table 2 demonstrates the outcomes of estimated Sunshine and global solar radiation of three areas situated at the west and north of Iraq; Haditha, Beji and Samara, these outcomes have been estimated for a period of 17 years [39].

Table 1. Sunshine and global solar radiation estimated from measured meteorological data values for a period of 2004-2008 years [38]

\begin{tabular}{ccccccc}
\hline Month & \multicolumn{2}{c}{ Baghdad } & \multicolumn{2}{c}{ Mosul } & \multicolumn{2}{c}{ Rutba } \\
& $\begin{array}{c}33.22 N, 44.23 \mathrm{E} \\
\text { Sunshine } \\
\text { [hour] }\end{array}$ & $\begin{array}{c}\text { Solar irradiance } \\
\text { MJ/m2 day }\end{array}$ & $\begin{array}{c}\text { 36.32N, 43.15E } \\
\text { Sunshine }\end{array}$ & $\begin{array}{c}\text { Solar irradiance } \\
\text { [hour] }\end{array}$ & $\begin{array}{c}\text { MJ/m2 day } \\
\text { Sunshine } \\
\text { [hour] }\end{array}$ & $\begin{array}{c}\text { Solar irradiance } \\
\text { MJ/m2 day }\end{array}$ \\
\hline Jan & 5.7 & 10.6 & 4.6 & 6.9 & 6.0 & 9.2 \\
Feb & 6.7 & 13.33 & 5.0 & 9.9 & 8.8 & 15.5 \\
Mar & 7.9 & 17.7 & 5.8 & 13.4 & 8.4 & 18.6 \\
Apr & 9.9 & 21.6 & 8.1 & 17.7 & 7.9 & 21.7 \\
May & 10.1 & 23.4 & 10 & 19.9 & 9.5 & 23.4 \\
June & 12.6 & 27.0 & 12.3 & 22.8 & 11.7 & 25.9 \\
July & 12.3 & 26.0 & 12 & 21.3 & 12.3 & 25.2 \\
Aug & 12.1 & 24.6 & 11.8 & 21.0 & 11.2 & 24.9 \\
Sept & 10.5 & 20.8 & 9.7 & 18.0 & 10.3 & 22.3 \\
Oct & 9.2 & 15.8 & 7.5 & 12.4 & 9.2 & 15.3 \\
Nov & 7.7 & 11.9 & 4.3 & 7.7 & 7.3 & 10.9 \\
Dec & 6.3 & 9.8 & 4.2 & 5.3 & 6.0 & 9.9 \\
\hline
\end{tabular}


Table 2. Sunshine and global solar radiation estimated from measured data (1995-2012) [39]

\begin{tabular}{ccccccc}
\hline Month & \multicolumn{2}{c}{ Haditha } & \multicolumn{2}{c}{ Beji } & \multicolumn{2}{c}{ Samara } \\
& Sunshine & MJ/m2 day & Sunshine & MJ/m2 day & Sunshine & MJ/m2 day \\
\hline Jan & 5.875 & 11.91 & 5.765 & 9.64 & 5.876 & 8.41 \\
Feb & 7.229 & 15.64 & 6.529 & 12.84 & 6.9 & 10.78 \\
Mar & 7.954 & 20.89 & 6.988 & 16.75 & 7.614 & 14.67 \\
Apr & 8.379 & 26.25 & 7.871 & 21.38 & 8.71 & 16.21 \\
May & 9.992 & 30.3 & 9.041 & 24.05 & 9.962 & 19.81 \\
June & 11.95 & 31.83 & 11.382 & 27.01 & 11.033 & 21.45 \\
July & 11.942 & 31.86 & 11.265 & 26.72 & 10.652 & 21.9 \\
Aug & 11.408 & 29.44 & 11.029 & 24.89 & 10.224 & 20.57 \\
Sept & 10.267 & 25.43 & 10.047 & 21.31 & 8.929 & 17.69 \\
Oct & 8.558 & 19.37 & 8.135 & 15.94 & 7.867 & 12.78 \\
Nov & 7 & 14.64 & 6.294 & 11.65 & 6.452 & 9.31 \\
Dec & 5.792 & 10.63 & 5.318 & 8.9 & 5.29 & 7.5 \\
\hline
\end{tabular}

Both Table 1 and Table 2 reveal the status of the sunshine and global solar radiation in Iraq. The measurements on horizontal surfaces that have the highest values at all considered locations appear in June, while the lowest values were in December, the annual average daily values for the global solar radiation on horizontal surface at Baghdad is $18.57 \mathrm{MJ} / \mathrm{m} 2 /$ day, at Mosul is $14.75 \mathrm{MJ} / \mathrm{m} 2 /$ day and at Rutba is $18.53 \mathrm{MJ} / \mathrm{m} 2 /$ day. In terms of solarity calculations, Iraq can be divided into three regions the north, the middle and south. These regions have an averaged from 16 to $10 \mathrm{MJ} / \mathrm{m} 2 /$ day for 5 months in the north, 6 months in the middle and southern region, respectively. But the most attractive and strategic place to build and develop solar plants in Iraq is the Al-Anbar province, the vast desert province in central-western Iraq, which have almost 8 months of sunshine duration while the lowest is over $4 \mathrm{MJ} / \mathrm{m} 2 /$ day. This level of energy is entirely adequate to run all the photovoltaics (PV's), concentrated solar power (CSP) and houses hold facilities such as heating, cooling and water distillation along the year [14]. Therefore, solarity and geography represent a strong foundation pillar for Iraq's solar power opportunity and future.

\subsection{The reduction in hydropower generation in Iraq.}

Hydropower generation represents the only current form of renewable energy in Iraq, accounting for nearly $10 \%$ of the electricity generation mix in 2010 (around $5 \mathrm{TWh}$ ) [25]. The decline in the precipitation rate projected for the future years and the related reduction in water availability is expected to decrease Iraq hydroelectric production in the future. As shown in Table 3, Iraq hydropower is generated from the dams built on the Euphrates and Tigris rivers and their tributaries [40]. A significant percentage of Iraq's water resources originates from outside its international boundaries, mainly from Turkey and Iran. Therefore, Iraq is highly vulnerable to the development plans of upstream states. As a result of dams already built on the Euphrates and Tigris, the analysis confirmed that the current annual flow of the Euphrates and Tigris entering Iraq has dropped dramatically [41]. Estimates suggest that the flow of water to Iraq from Euphrates river has been reduced by 20 per cent, and it is suggested that the rivers' flow could be reduced still further due to Southeastern Anatolia Project in Turkey, known as GAP in Turkish, possibly by 50\% [42]. The Southeastern Anatolia Development Project involves the construction of 22 dams and 19 hydroelectric power plants, with an installed capacity over $7.5 \mathrm{GW}$ on the Euphrates and Tigris rivers. This project once completed, will have a tremendous flow impact on the downstream countries, namely, Iraq and Syria [18].

Although this decline in water levels can be attributed to many factors such as dam construction in Turkey and Iran, an increased withdrawal of water for irrigation, population growth and the absence of an effective water resource management in Iraq, years of drought have evidently reduced the runoff in the river basin, especially in the Tigris River. Taking into consideration the predicted decline in precipitation due to climate change, a reduction in the levels of water in the Tigris and Euphrates is expected for the coming years, which could change future hydrologic conditions in Iraq and, as a result, future hydro power generation [43]. 
Table 3. The hydro power plants installed capacity in Iraq [40]

\begin{tabular}{ll}
\hline Project name & Installed capacity (MW) \\
\hline Dokan Dam & 400 \\
Darbandikhan Dam & 240 \\
Mosul Main Dam & 750 \\
Mosul Dam pump storage plant & 200 \\
Mosul Regulating Dam & 60 \\
Haditha Dam & 660 \\
Samaraa Barrage & 80 \\
Hemrin Dam & 50 \\
Adhaim Dam & 40 \\
Al-Hindiyah Barrage & 15 \\
Shatt Al-kuffa Regulator & 6 \\
Total installed capacity & 2501 \\
\hline Note: Data from 2011 &
\end{tabular}

\subsection{The limitation of wind energy in Iraq}

Compared to solar energy, wind energy is too limited in Iraq. The current proposed wind power projects exist in specific locations according to the wind availability there [44]. Al-Azzawi and Zeki [45] conducted a comparative study, comparing the characteristics of wind power resources and solar radiation energy of some meteorological stations in Iraq, the results showed that the wind power potentials in Iraq are relatively small (but not neglected) in comparison with solar energy. Wind power resources increase as one moves from the northern regions towards the southern regions. Another recent study by Hassoon [46] to assess the potential wind energy in the north of Iraq, concluded that the average wind speed is below the minimum speed, $5.0 \mathrm{~m} / \mathrm{s}$, needed for wind-electric generation. The highest average wind speed is recorded in July about $4.5 \mathrm{~m} / \mathrm{s}$ in Tikrit station where an energy of $13.5 \mathrm{kWh} / \mathrm{m} 2$ could be extracted. Although the coastal and offshore environment is windier, Iraq's Gulf coastline is only $58 \mathrm{~km}$ in length (see Figure 5) [47], where the priority is given for oil terminals. Such siting constraints may limit the utilization of offshore wind power, which is considered the most suitable areas for wind energy generation.

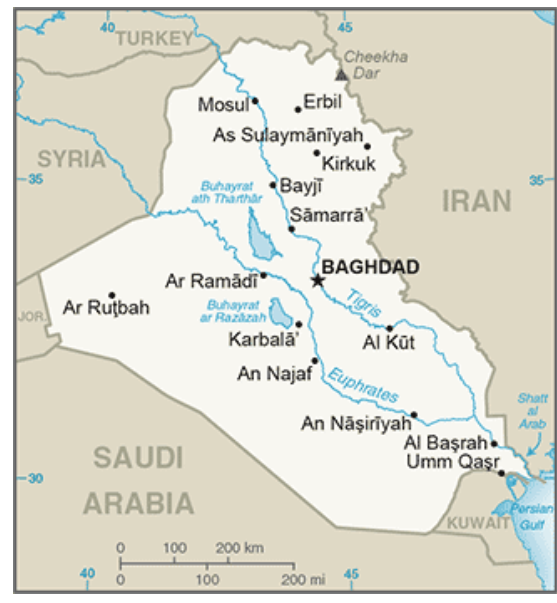

Figure 5. Map of Iraq and border nations. (From: www.cia.gov on 10 January 2016) [47]

\subsection{Challenges, difficulties and restrictions on the use of nuclear resources}

Nuclear energy is another low-carbon power generation method that accounts for approximately $20 \%$ of world electricity. However, in March 2011, the Fukushima incident changed the public perception of nuclear power, and a result, renewable energy technologies are rapidly gaining ground and nuclear power investment is declining in many states [48]. Generally speaking, nuclear energy has the public perception of being unsafe, and Iraq nuclear history is no exception.

Iraq is a member of the International Atomic Energy Agency (IAEA) since 1959, and began a preliminary program to establish and build a nuclear technology and staff, during its membership of Baghdad Pact, which included: Iraq, Iran, Turkey, and Pakistan [49]. Iraq acquired the first research nuclear reactor in 1967, which started operation with 2 MW energy capacity. It was equipped with facilities for nuclear experiment and research. The location was at the Nuclear Research Center at Tuwaitha, $15 \mathrm{~km}$ south 
of Baghdad [50]. The research use of this reactor was limited to material properties; medicine and agriculture research, but also initiated the thinking of the use of nuclear technology for electrical power generation [51]. In 1981, the completion of Iraqi second reactors with 40 MW thermal capacity was announced, which was constructed and installed by the French Alternative Energies and Atomic Energy Commission CEA and other sources. The second reactor, which was called Tammuz $1 \mathrm{TZ1}$, was supported by nuclear research facilities. Unfortunately, this strategic project was seen by two regional countries as a threat, namely, Iran and Israel. On 30 September 1980, an air strike called Operation Scorch Sword was conducted by the Islamic Republic of Iran Air Force, this attack caused only minor damage to the reactor and wasn't successful in impeding the Iraqi nuclear program [52]. The reactor was fully destroyed about eight months later by Israeli Air Force's Operation Opera carried out on 7 June 1981 [53].

In 1984, Iraq in cooperation with International Atomic Energy Agency (IAEA) planned to build nuclear power plants for electricity generation purpose, relying on 30 years of experience in nuclear technology, including reactor researches [51-54]. The Iraqi Atomic Energy Commission, IAEC signed a contract with Former Soviet Union FSU Atomenergoexport company to construct nuclear power plants for electricity generation. This contract was designed to be executed through stages. The first stage was site selection, followed by the second stage of the program in 1986, involving the studies about the following aspects: topography and geography; seismology and seismotectonics; geology; hydrology and cooling conditions; demography and land use; meteorology and aerology; ecology; electric transmission and grid stability. It also included the undertaking of the task of training personnel for operation and maintenance of the plant by the contractor. It was anticipated that by 2000 Iraq to generate $2 \mathrm{GW}$ of electricity from two nuclear power plants built on two sites, which was supposed to be chosen from the four suggested sites: Al-Mahzam, AI-Abasia, Abu-Dalaf and Baiji [55].

Following the end of the Gulf War in 1991, UNSC Resolution 687 directed the IAEA to find and dismantle Iraq's nuclear program, and guarantee Iraqi compliance with the Non-Proliferation Treaty or NPT through comprehensive ongoing monitoring and verification. Between May 1991 and October 1997, the IAEA finished a series of 30 inspection campaigns, supervised the destruction and disablement of nuclear facilities, and removed all weapons-usable nuclear material from Iraq [56]. In 2009, Ministery of Science and Technology announced that Iraq would explore the feasibility of developing a peaceful nuclear program for research purposes and electricity generation, considering the growing demand for electricity [57]. However, domestic instability and cost considerations halted Iraqi government plans from pursuing nuclear power or other nuclear technologies at that time. Currently, Iraq's nuclear capabilities are limited to medical and agricultural applications, which is a normal result of years of inspections, sanctions and conflicts. All of the above-mentioned challenges do not encourage the use of nuclear power as a source of renewable and low-carbon energy in Iraq [58].

\section{CONCLUSIONS}

The impact of wars, of underinvestment in the power sector, and rapidly growing electricity demand have created a shortage of - and desperate need for - a reliable and environmentally friendly source of power in Iraq. Renewable energy resources, such as solar, wind, and hydro are potential solutions to the Iraq electricity growing demand. The potential for utilizing renewable energy sources for electricity production in Iraq is found to be limited in comparison with solar. The solar energy density in Iraq is among the highest in the world. But solarity and location are only one aspect of Iraq's solar power opportunity. Therefore, it becomes necessity for significant investment to develop the solar energy infrastructure in terms of shared or localized plants with viable storage capacity to help meet the growing electricity demands in Iraq. In addition, the country's electricity sector policies need to be reformed, and are required to promote the deployment and utilization of renewable energy, and solar in particular.

\section{REFERENCES}

[1] Kazem Hussein, "A. Renewable Energy in Oman: Status and Future Prospects," Renewable and Sustainable Energy Review;vol. 15, no. 8, pp. 3465-3469, 2011.

[2] Chaichan M T, Kazem Hussein A., "Thermal storage comparison for variable basement kinds of a solar chimney prototype in Baghdad - Iraq weathers," International Journal of Applied Science (IJAS), vol. 2, no. 2, 2011.

[3] Hosenuzzaman M, Rahim NA, Selvaraj J, Hasanuzzaman M, Malek ABMA, Nahar A. "Global prospects, progress, policies, and environmental impact of solar photovoltaic power generation," Renewable Sustainable Energy Rev,;vol. 41, pp. 284-297, 2015.

[4] Solangi KH, Islam MR, Saidur R, Rahim NA, Fayaz H., “A review on global solarenergy policy,” Renewable Sustainable Energy Rev, vol. 15, pp. 2149-2163, 2011.

[5] Lux Research, Losing Power: Evaluating the Drivers and Impacts of Module Degradation, 2014. 
[6] EPIA, Global market outlook for photo-voltaic 2013-2017, European Photovoltaic Industry Association; 2013.

[7] Celik AN., "Present status of photovoltaic energy in Turkey and life cycle technoeconomic analysis of a gridconnected photovoltaic-house," Renewable Sustainable Energy Rev, vol. 10, no. 4, pp. 370-387, 2006.

[8] Masson G., Latour M., Rekinger M.,Theologitis I.T., Papoutsi M., "Global marketoutlook for photovoltaics 20132017," [Online] Available: www.epia.org/news/publications/.

[9] Devabhaktuni V, Alam M, Depuru SSSR, GreenII RC, Nims D, Near C., "Solar energy: trends and enabling technologies," Renewable Sustainable Energy Rev, vol. 19, pp. 555-564, 2013.

[10] Inman RH, Pedro HTC, Coimbra CFM, "Solar forecasting methods for renewable energy integration," Prog Energy Combust Sci, vol. 39, pp. 535-576, 2013.

[11] Lewis, D., "Iraq electricity: the untold story," Power Econ, 4 Nov, 2004.

[12] Lewis, D.,.,'Iraq's other power struggle," IET Power Eng, 18-21 Oct/Nov, 2006.

[13] Ministry of Planning- Republic of Iraq (MOP), National Development Plan forthe Years 2010-2014, Ministry of Planning of Iraq, Baghdad, 2010.

[14] Ali A. Kazem , Miqdam T. Chaichan, Hussein A. Kazem, "Dust effect on photovoltaic utilization in Iraq: Review article," Renewable and Sustainable Energy Reviews, vol 37, pp. 734-749, Sep 2014.

[15] IKN (Iraq Knowledge Network), Iraq Knowledge Network Survey 2011, Iraq Central Statistics Organization/Kurdistan Region Statistics Organization/United Nations, Baghdad, 2012.

[16] Hassoun, N., Al Monitor, Retrieved from: http://www. Al monitor.com/pulse/politics/ 2012/08/iraq-accusationsofsquandering.html, Aug 2012.

[17] Brinckerhoff P., Final report on the survey of private generation in the Baghdad Governorate, Baghdad: Parsons Brinckerhoff; 2009.

[18] Istepanian, H. Iraq's electricity: from crisis to ISIS, Powerengineeringint.com, [online] Available: http://www.powerengineeringint.com/articles/print/volume-22/issue8/features/iraq-s-electricity-from-crisis-toisis.html, 2014.

[19] Al-Khatteeb, L. and Harry, H. "Mean replace it with no number Harvard one," [online] Available at: http://TURN A LIGHT ON: ELECTRICITY SECTOR REFORM IN IRAQ, 2015.

[20] Istepanian, H. “Iraq's Electricity Crisis,"The Electricity Journal, vol. 27, no. 4, pp.51-69, 2014.

[21] El-Katiri, L., Fattouh, B., and Segal, P. "Anatomy of an Oil-Based Welfare State: RentDistribution in Kuwait', Kuwait Programme on Development, Governance and Globalisation inthe Gulf States, London School of Economics," [Online] http://www2.lse.ac.uk/government/research/resgroups/kuwait/documents/Fattouh.pdf, 2011.

[22] United Nations, World Population Prospects: The 2010 Revision. [Online] Available: http://www.un.org/en/development/desa/population/publications/pdf/trends/WPP2010/WPP2010_VolumeI_Comprehensive-Tables.pdf, 2010 .

[23] Ministry of Planning, National Development Plan for the Years 2010-2014, Republic of Iraq, Baghdad, 2010.

[24] Workman, D. "Crude Oil Exports by Country," World's Top Exports, [Online] Available: http://www.worldstopexports.com/worlds-top-oil-exports-country/, 2016.

[25] IEA, "Iraq Energy Outlook - World Energy Outlook Special Report," International Energy Agency, Paris. Retrieved from: www. worldenergyoutlook.org, 2012.

[26] Columbia SIPA, Center on Global Energy Policy, ISSUE BRIEF: IRAQ'S OIL SECTOR, 2014.

[27] BP (2012), BP Statistical Review of World Energy 2012, BP, London.

[28] O \& GJ (Oil and Gas Journal), "Worldwide Look at Reserves and Production," Oil and Gas Journal, vol. 109, no. 49, Pennwell Corporation, Oklahoma City, United States, $2011 \mathrm{a}$.

[29] International Energy Agency , "Fact Sheet for Oil Supply in Iraq," [Online] Available : http://www.iea.org/media/Factsheet_OilSupplyInIraq.pdf, 2014.

[30] Baker, J.A., Hamilton, L.H., The Iraq Study Group Report: The Way Forward - A New Approach, Vintage Books: A Division of Random House, Inc., New York, 2006.

[31] Ekren O, Ekren BY, Ozerdem B., "Break-even analysis and size optimization of a PV/wind hybrid energy conversion system with battery storage - a case study," Applied Energy, vol. 86, no. 78, pp. 1043-1054, 2009.

[32] Kazem Hussein A, and Miqdam T. Chaichan, "Status and future prospects of renewable energy in Iraq," Renewable and Sustainable Energy Reviews, vol. 16, pp. 6007-6012, 2012.

[33] Petter Pilesjo, Sameer Sadoon Al-Juboori, "Modelling the Effects of Climate Change on Hydroelectric Power in Dokan, Iraq," International Journal of Energy and Power Engineering, Special Issue: Modeling and Simulation of Electric Power Systems and Smart Grids, vol. 5, no. 1-2, pp. 7-12, 2016.

[34] Doyle, P. and Jaafar, K. "Iraq has an opportunity to become a solar leader," [Online] Available: http://www.iraqi datepalms.net/Uploaded/file/SolarEnergyLeaderDAIDevelopmentsarticle.pdf, 2010.

[35] Abbas MA, Elnesr MK., "Cloudiness and estimation of incoming solar radiation in Iraq," Pure Appl Geophys, vol. 112, pp. 234-239, 1973.

[36] Abed FM, Mohammed GHY, "Empirical models for the correlation with sunshine duration of metrological data for Tikrit-TuzKhurmato and KirkukIraq," Tikrit J Eng Sci, vol. 19, pp. 1-13, 2012.

[37] Abdul-Wahid SN, Hassan AM, "Calculation and applications of net solar radiation in Iraq," J Al-Qadisiyah Pure Sci, vol. 15, pp. 1-30, 2010.

[38] Al-Salihi AM, Kadum MM, Mohammed AJ., "Estimation of global solar radiationon horizontal surface using routine meteorological measurements for different cities in Iraq," Asian J Sci Res, vol. 3, pp. 240-248, 2010.

[39] Abed FM, Al-Shahery GhYM, "Estimation of global solar radiation on horizontal surfaces over Haditha, Samara, and Beji, Iraq," Pac J Sci Technol, vol. 11, pp. 73-82, 2010. 
[40] Liu, H., Masera, D. and Esser, L., eds. "World Small Hydropower Development Report 2013," United Nations Industrial Organization; International Center on Small Hydro Power, [Online] Available: www.smallhydroworld.org, 2013.

[41] UNESDOC, Integrated drought risk management - DRM national framework for Iraq - executive summary, report from: UN Educational, Scientific and Cultural Organization, 13 Oct 2013.

[42] Kurdish Human Rights Project, The Ilisu Dam Campaign, and The Corner House, Downstream Impacts of Turkish Dam Construction on Syria and Iraq: Joint Report of Fact-Finding Mission to Syria and Iraq, [online] Available: www.thecornerhouse.org.uk/sites/thecornerhouse.org.uk/files/IraqSyri.pdf, 2002.

[43] Pilesjo, P. and Al-Juboori, S. "Modelling the Effects of Climate Change on Hydroelectric Power in Dokan, Iraq," International Journal of Energy and Power Engineering., vol. 5, no. 2-1, pp.7-12, 2015.

[44] Alrikabi, N. "Renewable Energy Types," Journal of Clean Energy Technologies, vol. 2, no. 1, pp. 61-64, 2014

[45] S.I. Al-Azzawi, N.A. Zeki, "Comparison between the characteristics of wind power calculations and solar radiation energy of some meteorological stations in Iraq," Solar \& Wind Technology, vol. 4, no. 4, pp. 513-516, 1987.

[46] Ahmed F. Hassoon, "Assessment potential wind energy in the north area of Iraq," International journal of energy and environment, vol. 4, no. 5, pp. 807-81, 2013.

[47] CIA World Factbook, "Iraq country study," Central Intelligence Agency, [Online] Available: https://www.cia.gov/library/publications/the-world-factbook/geos/iz.html, 2016.

[48] S.-h. Park, W.-J. Jung, T.-H. Kim, S.-Y.T. Lee, "Can Renewable Energy Replace Nuclear Power in Korea? An Economic Valuation Analysis," Nuclear Engineering and Technology, vol. 48, no. 2, pp. 559-571, 2016.

[49] Selbi D, Al-Chalabi Z, Khadduri IY, Untold milestones in the Iraqi national nuclear program 1981-1991, Beirut: Arab Scientific Publishers, 2011.

[50] Ahmed SA, Omer MA, Abdulahad AA., "Analysis of wind power density in Azmar mountain (Sulaimani RegionNorth Iraq)," Eng Res Appl, vol. 2, pp. 1403-1407, 2014.

[51] Abdulkhaliq H, Alhijjaj A., The strategy of the nuclear program in Iraq withinthe context of science and technology policies, Beirut: Center for Arab Studies, 2011.

[52] Neil Narang, Erik Gartzke \& Matthew Kroenig, Nonproliferation Policy and Nuclear Posture: Causes and Consequences for the Spread of Nuclear Weapons, Routledge Press, 2015

[53] Tucker, Spencer C. The Encyclopedia of the Arab-Israeli Conflict: A Political, Social, and Military History, Santa Barbara: ABC-CLIO, pp. 755, 2008.

[54] IAEC Iraqi Atomic Energy Commission, Annual report 1981, [Online] Available: http://www.iraqwatch.org/government/Index_Iraq.htm, 1981.

[55] IAEC Iraqi Atomic Energy Commission, Annual report 1985, [Online] Available: http://www.iraqwatch.org/government/Index_Iraq.htm, 1985.

[56] Mohamed ElBaradei, The Age of Deception: Nuclear Diplomacy in Treacherous Times, New York: Metropolitan Books, pp. 31, 2011.

[57] Martin Chulov, Iraq goes nuclear with plans for new reactor programme, The Guardian, Oct, 2009.

[58] U.S. Department of State, U.S. and Iraq Sign a Joint Action Plan to Combat Nuclear and Radioactive Smuggling, Press Release, Sep 3, 2014, [Online] Available: www.state.gov. 